\title{
P-31 LOWER AND MIDDLE MIOCENE CARBONATE AND MIXED CARBONATE/SILICLASTIC SYSTEMS IN THE MUT BASIN OF SOUTH CENTRAL TURKEY - DEPOSITIONAL GEOMETRIES, ECOLOGICAL CHANGE AND STRATIGRAPHIC CONTROL
}

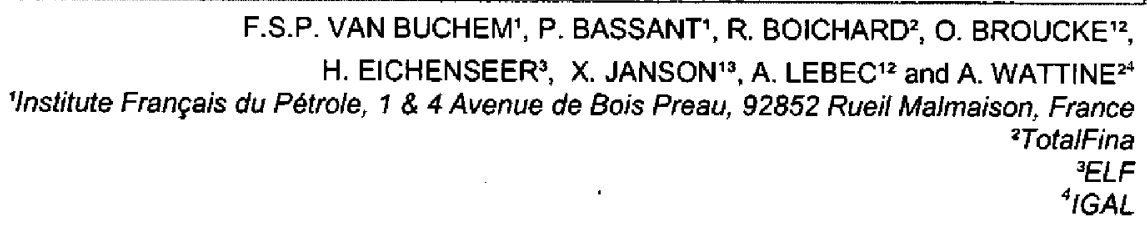

The Mut basin, located in south central Turkey, shows exceptional three dimensional exposures of an approximately 800 meter thick succession of Lower and Middle Miocene carbonates. This basin, that covers an area of about 80 by 100 kilometers, has been object of a number of studies over the last four years (X. Janson, 1997; O. Broucke, 1998; A. Lebec, 1999; P. Bassant, 1999), of which the results are summarised in this paper. The main objectives of the study. of these carbonate platforms are: 1) to investigate the relationship between depositional geometries and sedimentary facies in both the carbonate and mixed carbonate/siliciclastic settings, 2) to determine the variation of the depositional geometries in different depositional environments in the same basin, and 3) to understand the relative influence of tectonism, eustatism and climate on the sedimentation pattern.

The Lower Miocene and Middle Miocene in the Mut basin (Burdigalian and Langhian) was a time of relative tectonic quiescence, during which a complex relict basin topography was flooded by a rapid marine transgression. The Mut basin was connected with the open sea (the Neotethys) through a small seaway in the Silifke area. The strong relict topography, in combination with the local influx of siliciclastics created many different depositional environments in this subbasin. Two regions have been studied in detail to demonstrate both the lateral and vertical variation in facies and geometries: the Mut and Silifke areas for the Lower Miocene deposits (P. Bassant, 1999), and the Ermenek area for the Middle Miocene deposits (X. Janson, 1997; O. Broucke, 1998; A. Lebec, 1999). The methodology used is the high resolution sequence stratigraphy. Transects were constructed by combining detailed sedimentological observations on the macrofacies and microfacies and stratal geometries in a high resolution time framework.

In the Lower Miocene (Burdigalian) succession of the Mut basin, three different depositional environments have been studied: a carbonate dominated margin, a mixed carbonate/siliciclastic margin, and a narrow strait connecting the Mut basin with the Neotethys (Bassant, 1999). High resolution sequence stratigraphic analysis, in combination with nannofossil dating, provides the time framework within which these three sites can be compared. The main controlling factor on the sedimentation pattern are fluctuations in relative sea level, but depositional geometries, texture and lithology are demonstrated to be extremely variable and are strongly controlled by local siliciclastic influx, paleotopography, and ecological change. 
In the Middle Miocene (Langhian) of the Ermenek region the relationship between depositional geometries and facies distribution are studied in a 250 meter thick and 2 kilometer long margin to platform transition: The margin outcrops show exceptionally well preserved depositional geometries that allow to define depositional sequences based on volumetric partitioning (Janson, 1997). Transgressive hemicycles show isopacheous geometries, and regressive hemicycles are sigmoidal shaped. Further work showed a good coherency between these geometries and the facies distribution (a dominance of deeper water facies in the isopachous, and shallow facies in the sigmoids) (Broucke, 1998). In the intraplatform, some of the higher frequency cycles are missing, and only the $4^{\text {th }}$ order floodings are registered. An overall evolution of the ecosystem is demonstrated with a ramp type system dominated by red algae, oysters and benthic forams (foramol) in the lower part, and a more platform type morphology with a fauna dominated by corals and porcelaneous forams (Miliolids and Alveolinids) in the upper part (Lebec, 1999).

The Miocene deposits in the Mut basin show a dominant control of accomodation space variations (relative sea level) on the stratigraphic architecture, but a large variety of depositional geometries is caused by local and/or temporal variations in siliciclastic influx, paleotopography and ecological change.

\section{References:}

Bassant, P., 1999, The high-resolution stratigraphic architecture and evolution of the

Burdigalian carbonate-siliciclastic sedimentary systems of the Mut Basin, Turkey.

GeoFocus vol. 3 (Ph.D., Inst. de Géologie et Paléontologie de l'Université de Fribourg), p. 277

Broucke, O., 1998, Modélisation stratigraphique et étude de terrain d'un haut-fond carbonaté (secteur d'Ermenek, Bassin de Mut, Turquie). Mémoire DEA (ENSPM).

Janson, X., 1997, Etude des géométries et de la stratigraphie séquentielle haute résolution de la plate-forme carbonatée du bassin de Mut, dans la région d'Ermenek. Mémoire DEA (ENSPM)

Lebec, A., 1999, Etude séquentielle d'un haut-fond carbonaté du bassin de Mut dans la region d'Ermenek - géometrie et stratigraphie environmentale, modélisation 3D par GOCAD 3D et HERESIM. Mémoire DEA (ENSPM). 